\title{
Legal Relations and Legal Consequences of Wakālah Contract Implementation in Hajj Fund Deposit
}

\author{
Dewi Nurul Musjtari ${ }^{1}$, Syintia Widya Kencana ${ }^{2}$ \\ ${ }^{1}$ Faculty of Law, Universitas Muhammadiyah Yogyakarta, Indonesia \\ dewinurulmusjtari@umy.ac.id \\ ${ }^{2}$ Faculty of Law, Master of Notary Student, Universitas Gadjah Mada, Indonesia \\ shintyawidya@gmail.com
}

\begin{abstract}
Introduction to The Problem: Hajj financial management in Indonesia is entrusted to the Hajj Financial Management Agency (BPKH). The central point of controversy is whether or not a portion of the Hajj deposit funds are legally permitted to finance a government infrastructure program. Another problem that emerges in the controversy is the spreading issue regarding the obligation of candidates of the pilgrims of signing the Wakālah (agency) contract for the Hajj registration. It is assumed that the candidates must agree when the BPKH invests the Hajj fund in the infrastructure program.
\end{abstract}

Purpose/Objective Study: To analyze the legal relationship between Muwakkil (the principal) and Wakil (the agent) on the implementation of the Wakālah Contract for the pilgrimage fund deposit, categorizing the contract and the legal consequences of the use of hajj funds that are not following the purpose of the contract.

Design/Methodology/Approach: The research method uses normative research with statutes and legal approaches to the Wakālah contract. The technique of collecting data uses secondary data. Data were analyzed with qualitative descriptive. Findings: The legal relationship between the Muwakkil and the Deputy is based on the Wakālah Agreement. The existence of Wakālah contract in the Hajj fund deposit is a series with the aim of Muwakkil to run the Hajj. Therefore, the management of the hajj deposit funds should be based on applicable laws and regulations, the theory of authority, the theory of dispute resolution, and the purpose of the Wakālah Contract. The Legal relationship and consequences if the use of the Hajj deposit funds contradicts existing laws and agreements and is not in accordance with the intended use, it can have consequences that the Wakālah Contract will be null and void and if it contradicts the original agreement between Muwakkil and Wakiil then the Muwakkil can submit contract cancellation. In the event of a loss, the BPKH is responsible for compensating the Muwakkil in this case, the prospective pilgrims.

Paper Type: Research Article.

Keywords: Legal Relations; Legal Consequences; Wakālah Contract; Hajj Fund Deposit 


\section{Introduction}

The number of Indonesian citizens who register to perform the pilgrimage to Mecca (Hajj) continues to increase, although the hajj quota is limited (Muheramtohadi, 2019). As a result, the pilgrim waiting list is increasing as well, which means the Hajj fund managed by Hajj Financial Management Agency (BPKH). A similar opinion was expressed by M. Ali Mubarak and Ulya Fuhaidah (2018). If this Hajj fund accumulation is not appropriately managed, it will not only violate the contract and lead to corruption, but also engender a public distrust.

Problems arising in the management of Hajj finances include the unclear legal relationship between prospective pilgrims (Muwakkil) and the recipient of the hajj deposit bank (the agent) and the categorization of the contract. Also, the existence of Wakālah contract and its legal consequences in the event of misuse of Hajj financial management that is not in accordance with the purpose of the contract is not yet clearly known by the public, especially for prospective pilgrims. Previous research on Wakālah Agreement on Hajj financial management has been reviewed by Endang Jumali (2018), Research on Hajj Management conducted by Roikhan Muhammad Aziz (2018) and about the Investment Responsibility of Hajj management by BPKH reviewed by Erry Fitria Primadhany (2018).

The controversy arises when the issue of using the Hajj fund for governmental infrastructure projects through Wakālah (agency) contract is spreading in Indonesia. The main question in this polemic is whether it is normatively and legally acceptable to allocate a portion of the Hajj fund for the government's infrastructure program. Some argue that such allocation is violating contract agreement between the pilgrim and Hajj Financial Management Agency (i.e. Badan Pengelola Keuangan Haji, abbreviated as BPKH) since the fund is used for purposes unrelated to the Hajj. Others view the possibility of using the fund for infrastructure programs since Wakālah contract gives an authority to the wakill, BPKH, to manage the fund in any useful activities and investments as long the main purpose, which is facilitating the pilgrims for Hajj, is fulfilled. In short, this paper addresses this controversial question and examines whether the Hajj fund is permissible to fund the government's infrastructure projects from a normative and legal perspective.

Previous studies on the management of the Hajj fund focused on its sharia and financial aspects. The study of Ayu Azhara (2015), entitled "Management of Hajj Savings Funds Viewed from Islamic Economic Perspectives" explains the pooling system used by P.T. Bank Syariah Mandiri in managing bank funding sources. This system is a mechanism used by banks in managing funds collected from a community as well as a form of proof in carrying out responsibility and reflection on whether or not the sharia (Islamic law) principles are operating in the bank's performance as an intermediary. In this study, both the product and management of existing funds still have to adjust to or comply with the principles of Islamic economics. 
Nurul Izzati Septiana (2015), wrote a thesis entitled "Construction of the Financial Management Model of Hajj in Islamic Banks in Indonesia." In her thesis, she argues that the construction of hajj financial management can be done through a contract between the pilgrims and BPKH through wadi'ah yad al-dammānah agreement or musyārakah mutanāqișah contract.

Juju Jumena and his colleagues also conducted a study on the management of Hajj funds entitled "The Right of Hajj Pilgrims in the Management of the Initial Deposit of Hajj Costs." This study investigates what type of contract is used by prospective pilgrims when depositing initial pilgrimage costs (BPIH) and whether pilgrims are entitled to the results of the management of BPIH's initial deposit funds" (Jumena, Bustomi, \& Fatimah, 2018).

In addition to the different types of contract that had been studied above, the study of Wakālah (agency) contract between the prospective pilgrims (Muwakkil) and BPKH (wakill) is still limited. Therefore, this study aims to examine the legal and normative validity of Wakālah (agency) contract in the Hajj fund management by discussing what the legal consequences between Muwakkil (the principal) and Wakīil (the agent) in Wakālah Contract (agency).

\section{Methodology}

The research method uses normative research with a legal and legal approach to Wakālah contract. The technique of collecting data uses secondary data. Data were analyzed with qualitative descriptive. Secondary data in this study, obtained through library research and legal documents, which include: 1) Primary Legal Materials, which consist of: a) Al-Qur'an, Hadith and several rules and regulations and Fatwa 2) Secondary Legal Materials, consisting of books on Contracts, Agreements, Dispute Resolution and Authority Theory, legal research methodologies, articles on journals, previous research relevant on the topic and materials downloaded from the internet. Data collection techniques are carried out by hermeneutics, legal sociology and phenomenology.

Data found in library research are classified first, then will be processed based on qualitative descriptive analysis. Based on this understanding, what is meant by descriptive qualitative is an analysis that describes the legal relationship and its legal consequences between the Muwakil and the Deputy in the Wakālah Agreement on the pilgrimage fund deposit.

\section{Results and Discussion}

\section{Authority Theory}

The term authority or authority resembles with the concept of 'authority' in English and bevoegdheid in Dutch. The Authority in the Black's Law Dictionary is defined as the right or permission to act legally on another's behalf (Garner, 2009). Philipus M. Hadjon presents three kinds of authority in legislation which include attribution, 
delegation, and sometimes also mandate. Attribution is the authority to make decisions (besluit) which are directly derived from the law in a material sense. Delegation is passing authority from a governmental body to another governmental organ. With the delegation of the authority, it comes to the responsibility as well. The mandate is the delegation of authority to a subordinate to make decisions on behalf of state administrative officials. The responsibility does not move from the mandating officials to the mandates but remains with mandating agents (Hadjon, 1997).

According to Bagir Manan as quoted by Nurmayani authority in legal language is not the same as power. Power only reflects the right to do and not do. At the same time, authority means rights and obligations (Nurmayani, 2009). Ridwan HR believes that authority is the right to use the authority possessed by an official or institution according to the applicable provisions; thus, the authority also concerns the competence of legal actions that can be carried out according to formal methods, so the authority is the formal power possessed by the official or institution. Authority has an important position in the study of constitutional law and state administrative law that FAM Stroink and J.G. Steenbeek called it a core concept in state administrative law and state administration law (Ridwan H.R., 2013; Stroink \& Steenbeek, 1989).

In the management of hajj finances, the government delegates to BPKH. This decision is based on the Theory of Authority, as stated by several experts mentioned above. The authority in BPKH is in accordance with the theory of authority and has been based on Law No. 34 of 2014 and other related regulations.

\section{Theory of Dispute Resolution}

In the event that there is a financing problem, the bank maintains its liquidity by trying to resolve it. According to Rahmadi Usman, dispute resolution in English vocabulary consists of 2 (two) words, namely 'conflict' and 'dispute' which both contain an understanding of contradicting interests in which two or more parties are involved. Meanwhile, the vocabulary 'dispute' refers to a situation where 2 (two) parties or more are confronted with differences of interests. This situation will not develop into a dispute if the party who feels disadvantaged only refrains from expressing his/her dissatisfaction or concern. A conflict changes or develops into a dispute when the party who feels aggrieved has expressed dissatisfaction or concern, both directly to the party that is considered to be the cause of the loss or to the other party (Usman, 2003).

Financial management of the pilgrimage is part of the Islamic economy. Suppose it is based on Article 49 letter (i) of Law No. 3 of 2006 as amended by Law No. 50 of 2009 (Law No. 50, 2009). Then the pilgrimage financial management can be categorized in sharia business. Therefore, in the event of a problem, dispute or conflict, the institution that can resolve it is based on the Religious Court or the National Sharia 
Arbitration Board (i.e. Badan Arbitrase Syariah Nasional, abbreviated as Basyarnas). It is also emphasized related to the resolution of Islamic economic disputes after the entry into force of the Constitutional Court Decision No. 93/PUU-X/2012 and Supreme Court Regulation No. 14 of 2016 on Procedures for Settling Sharia Economic Disputes (PERMA No. 14, 2016)

\section{Concept of Wakālah Agreement on Haji Fund Deposit}

\section{Understanding of Wakālah Agreement}

Etymologically Wakālah is giving authority or power. Wakālah can be interpreted as a delegation of authority from an authorizing agent to a recipient in certain matters. If the recipient of the authority has carried it out under an authorization contract, all risks and responsibilities for the implementation of these matters are fully in the hands of the recipient (Abu Sulaiman, 2006).

\section{Legal basis for Wakālah contract}

The Islamic legal rule for the Wakālah Agreement is permissible. It means that someone may delegate a specific action to someone else. A person who represents it, acts for and on behalf of the represented, insofar as the authorized matters can be delegated. The arguments used to show this ability include:

1. The Word of God Almighty in Surah Al-Nisa, verse 35. Which means: then send a messenger from a male family and even a female family;

2. Surah Al-Kahf, verse 19, which means: then send one of you to go to the city with your silver money.

In addition to the two Words of God above, the other legal basis is the Hadith of Bukhari's collection, Abu Hurairah said, "The Prophet (peace and blessings of Allah be on him) has represented to me to maintain the zakat fitrah, and he has given a goat to Uqbah bin Amir to be distributed to his friends" (Narrated by Bukhari). Another legal basis is the Fatwa of the National Sharia Council Number: 10/DSNMUI/IV/2000 concerning Wakālah (Fatwa DSN No. 10, 2000).

Some other regulations relating to the Wakālah contract in the Hajj fund deposit are also based on:

1. Law Number 34 of 2014 concerning Management of Financial Hajj (Muneeza, Sudeen, Nasution, \& Nurmalasari, 2018);

2. Law Number 13 of 2008 concerning the Implementation of Hajj (Jayaprawira \& Abdussalam, 2019; Zubaedi, 2016);

3. Presidential Regulation Number 110 of 2017 concerning the Hajj Financial Management Agency.

Pillars and Wakālah Contract Terms

According to Sulaiman Rasyid, there are 4 (four) pillars of Wakālah Agreement as below (Rasyid, 1991): 
1. Representative. The conditions for representing are that which represents is the owner of goods or goods that are under his control. The representative party can act on the property if the representative is not the owner, then the Wakālah is cancelled;

2. Deputy (representing), the conditions for the Representative are people who have a reason if a representative is crazy or immature, then the Representative is null and void. According to Hanafi School, young children who can distinguish good and bad are legitimate to be representatives;

3. Muwakkal Fīh (something that is represented), the terms of something represented are:

a. The work may be replaced by someone else to do it, so it is legitimate to represent it to do worship such as prayer, fasting, reading the verses of the Koran because this cannot be represented;

b. The work belongs to the Representative when he is a representative. Therefore, it is illegitimate to represent the goods that they do not have;

c. The work is known, then cancel represents something that is still vague. Like someone said: "I made you my representative to marry one of my children."

4. Sigat that is representing deputation, lafäz is pronounced from the Representative as a symbol of his blessing to represent, and the Representative accepts it. Representatives must not also represent other people, except with an authorized permit or by force, for example, the work represented is so extensive that it cannot be done by the Representative alone, so he may represent the work he cannot do. In this case, it is known as the Substitution Right, which is the right to delegate to another party or person based on the agreement of the party represented.

Based on the Fatwa of the National Sharia Council Number: 10/DSN-MUI/IV/2000, rukun and Wakālah conditions, namely as follows: "that the Muwakkil (who represents) is as a legitimate owner who can act on something that is represented; mukallaf or mumayyiz child (can distinguish between right and wrong) within certain limits, namely in matters that are beneficial to him such as representing to receive alms, and on. While the Representative (who represents) that must be competent law, can do the tasks represented by him, representatives are people who are given the mandate. Ali said that "fundamentally, the management of the Hajj fund has been carried out using the Wakālah contract. The Fatwa of DSNMUI No. 10/DSN-MUI/IV/2000, mentions that Wakālah is the authority delegation by one party to another party for matters that are representable. Furthermore, the Fatwa of DSN-MUI Number 122/DSN-MUI/II/2018 (Fatwa DSN MUI No. 122, 2018), states that Wakālah agreement is the authority delegation from the prospective pilgrims to the government to manage the given objects" (Ali, 2019).

Things that can be represented using the Wakālah principle include (Ali, 2019): 
1. A thing (certain legal actions) that is known by the person who represents it. So, in granting a power of attorney, the authorized person must understand the intent or legal action authorized by the authorization.

2. Does not conflict with Islamic law. Giving such power may not be for a purpose that is contrary to Islamic law, for example, the power to conduct a physical transaction (evil).

3. Can be represented according to Islamic law.

If one of the parties does not fulfil its obligations or if a dispute arises between the parties, the settlement is carried out through the Sharia Arbitration Board after the agreement is reached without agreement.

Types of Wakālah Agreement

Wakālah consists of several types, namely (Purnamasari \& Suswinarno, 2011):

1. Al-Wakālah Al-Muțlaqah, which is representing absolutely without limits of time and for all matters to represent all the needs of the person who represents but only for acts of management (beherent);

2. Al-Wakālah Al-Muqayyadah, which is the power of attorney to act on behalf of the person who represents in certain matters. This power is usually reserved for certain legal actions relating to ownership of an item, or making peace, or other actions that can only be carried out by the owner of the goods;

3. Al-Wakālah Al-Amämah, which is a representative who is usually designated for daily management. Wakālah, often used as a complement to a contract transaction or as a bridge to the limitations of the implementation of the contract.

\section{End of Wakālah Agreement}

The Wakālah contract ends because of several reasons, including (Suhendi, 2014):

1. The death of one of the faithful can cause the end of the Covenant. Due to the fact that one of the legal requirements for a contract is a person who is still alive;

2. If one is insane, because the legal requirements of one of the mindful people have reason or reason;

3. Termination of the intended work;

4. The Wakālah Agreement is decided by one of the participating parties, either the authorizing party or the party receiving a power of attorney;

5. The release of the person representing the ownership status.

\section{The Concept of Unnamed Contracts}

A nameless contract is allowed because the rules of fiqh in muamalah are permissible as long as they are not prohibited. The availability of the Named Contract is also based on Article 1319 of the Civil Code, which states that all named and non-named agreements are subject to the general provisions of Book III of the Civil Code. The other legal basis is Article 1338 Paragraph (1) of the Civil Code which states "all agreements made legally apply as laws for the parties who make them). 
Based on the article implied the principle of freedom of contract. This principle implies that the parties are free to make any contract provided that it does not conflict with the legal terms of the contract, which must not conflict with law, decency and public order.

Other legal sources are based on doctrine, which is based on the opinion of Syamsul Anwar, a contract that is not specifically regulated in the books of fiqh under one particular name (Anwar, 2010). The nameless contract arises because of the interests of the parties and due to the growing needs of the community. The nameless contract, although not specifically regulated, must still fulfil the elements in the contract so that it can become lawful.

The elements that must exist in a contract include an essential element. Thus, something that must exist which is the main thing as a condition that should not be ignored and must be included in a contract, an element of naturalia which is a general legal provision concerning a condition that must exist after it is known essential elements and accidents, namely various special things stated in the contract agreed upon by the parties.

In addition to harmony and contract terms as mentioned above, the nameless contract must also fulfil the legal requirements of the contract; this is contained in Article 1320 of the Civil Code which regulates the legal conditions of the agreement, namely:

1. There is an agreement between the parties, namely an agreement that occurs without any mistakes; no coercion or fraud;

2. Able to make an engagement that is people who have grown up and are not under guard;

3. A certain matter that only goods that can be traded can become the principal of a contract which is at least determined by the type, it does not become an obstacle that the amount of goods is not certainly provided that the amount can then be determined and can be calculated;

4. A lawful reason (permissible), meaning that the contents of the contract are not prohibited by law or do not conflict with decency or public order, a contract made for the reason that is false or prohibited does not have legal force.

In connection with the legal terms of the agreement based on Article 1320 of the Civil Code is grouped into two. The first is called subjective conditions because it relates to the parties who make and implement the agreement. Terms that are categorized in subjective terms are 1 (first) and 2 (second) conditions. Both are called objective conditions because they are related to the object of agreement (contract). The conditions categorized as objective conditions are terms 3 (third) and 4 (fourth).

The requirements, according to Article 1320 of the Civil Code are also inline or not contradictory to the requirements based on An-Nisa: 29 which states: 


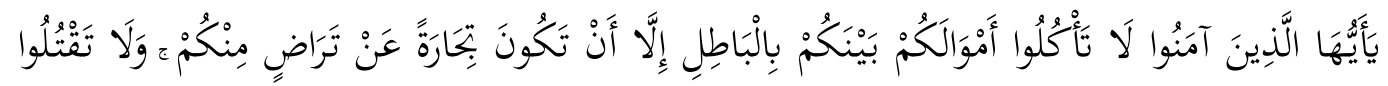

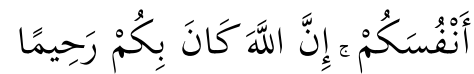

Translation: "O ye who believe, do not eat each other's wealth in a way that is vanity, except by way of commerce that applies with the likes of you. And do not kill yourself; indeed, Allah is the Most Merciful to you."

Based on the contents of the above verse of An-Nisa, it can be seen that in running a contract must be based on the likes ('an tarädin), likes and likes. Among the parties also must pay attention to other conditions, namely competent, the object must be clear (certain), not contain gharar elements and the cause (cause) of the contract is lawful. This means that it must not conflict with law, decency and public order.

The grouping of contract requirements mentioned above is intended for different consequences if the parties do not meet one of the contract requirements. The legal consequences if the subjective conditions are not fulfilled, the agreement (contract) can be cancelled. Whereas if one of the third and fourth requirements is not fulfilled, then the agreement (contract) of the legal consequences is null and void by law.

\section{The Legal Relationship between Muwakkil, BPIH and BPKH}

The Wakälah Agreement bounds the legal relationship between the prospective pilgrims (Muwakkil) and BPKH (the agent). As explained above, the Wakālah contract is the contract of the surrender of power, which in that contract, someone appoints another person as his substitute in acting (tașarruf). The legal basis for the Wakālah Contract is permissible, meaning that someone may delegate a certain action to another person. The person who represents it, acts for and on behalf of the authorizer or representative, insofar as the authorized matters can be delegated by religion.

The Wakālah Contract governs the legal relationship between prospective pilgrims (Muwakkil) and BPKH (the agent). With the above agreement, the Wakālah contract is a contract of the surrender of power, which in that contract appoints another person as his successor in battle. The legal basis for Wakālah approval is permitted, meaning that someone can delegate certain actions to another person. The person who represents it acts for and on behalf of the author or representative, discusses matters that are validated by religion. Prospective pilgrims will not be directly related to BPKH.

The legal relationship between prospective pilgrims occurs as a result of the Wakālah Contract made between the prospective pilgrims with the Hajj Recipient Bank (BPIH). Funds deposited by prospective pilgrims are poured into the Wakālah Agreement. The results of fund managers will be forwarded virtually from BPIH to $\mathrm{BPKH}$. During the waiting period for the departure of prospective pilgrims, the funds managed by BPKH will be optimized for the development of hajj funds. This is done 
with consideration to obtain a source of income to increase the cost of organizing the pilgrimage. Based on the results of interviews with Akhyar Adnan, a member of the BPKH Supervisory Board, one of the tasks delegated by the government to the BPKH was to develop a pilgrimage fund in obtaining additional costs in organizing the Hajj. In the management of the implementation of the pilgrimage calculation of the cost of Hajj for each prospective pilgrims requires about 70 (seventy) million. However, in practice, each prospective pilgrimage is only required to make the fee payment through BPIH each prospective pilgrimage of 35 (thirty-five million). The shortfall in the cost of conducting the Hajj will be borne by BPKH. Therefore, one source of funding can be obtained through investment.

Based on its function, BPKH is an institution that conducts financial management of Hajj. BPKH as the representative (the agent) is obliged to carry out everything that has been delegated to him while the Muwakkil (the principal) entrusts the management of the Hajj financial to the BPKH.

The existence of Wakālah contract in the Hajj fund deposit is a series made in order to optimize the management of Hajj fund deposits to realize the objectives of Muwakkil (prospective pilgrims) in carrying out Hajj services. This is regulated in Article 13 of Government Regulation Number 5 of 2018 concerning Implementation of Law Number 34 of 2014, that the payment of the initial deposit of BPIH and/or Special BPIH is accompanied by the filling and signing of the form of time contract by Muwakkil. The provisions of the type, format and requirements of the Wakālah contract are regulated by the Regulation of the Hajj Financial Management Agency (BPKH).

In the Wakālah contract, there is a clause stating that the Muwakkil will pay the initial deposit of Bank for Receiving Haj Contribution (BPIH) and/or Special BPIH giving power/time to the BPKH to manage all funds paid as BPIH and/or Special BPIH deposits and the value of the management benefits according to the mandate of legislation applicable laws. This is needed to ensure Muwakkil's willingness to represent $\mathrm{BPKH}$ to manage its funds.

The funds deposited by Muwakkil to the representative are not only Muwakkil's departure savings to the holy land but are managed by the BPKH for the development of BPIH, namely by buying Syariah Negara (SBSN) Securities; Government Securities and/or placing in the form of time deposits in accordance with Law Number 13 of 2008 concerning the Implementation of Hajj (Law No. 13, 2008).

BPKH is divided into two organs, namely the Executing Agency and the Supervisory Agency. The Executing Agency has the function of planning, implementing, and accountability and financial reporting of Hajj. The authority of the implementing organ is regulated in Article 18 of the Presidential Regulation Number 110 of 2017 
concerning the Hajj Financial Management Agency (PERPRES No. 110, 2017), namely:

1. Placing and investing hajj finance under shariah principles, prudence, security and the value of benefits;

2. Cooperating with other institutions in the framework of financial management of Hajj;

3. Establishing the organizational structure along with tasks and functions, work procedures or organization, and the personnel system;

4. Organizing BPKH staff management, including, appointing, transferring and dismissing BPKH employees and determining BPKH income;

5. Propose to the President through the Minister regarding income for the Supervisory Board and Executing Agency; and

6. Determine the provisions and procedures for the procurement of goods and services in the context of carrying out the duties of the BPKH and pay attention to the principles of transparency, accountability, efficiency and effectiveness.

BPKH has the responsibility in managing the hajj deposit funds stipulated in Article 17 of Presidential Regulation Number 110 of 2017 concerning BPKH namely compiling performance reports and financial reports on a monthly, quarterly, semester and yearly basis and compiling a Hajj Financial Management accountability report. The report is the material for the preparation of the Hajj financial accountability report to the President and Parliament through the Minister every 6 (six) months. Submission of the Report to the Minister no later than July 20 of the current year while the President and the DPR no later than July 31 of the current year.

The Supervisory Board has a supervisory function for planning, implementing, and accountability and Financial Reporting for Hajj. The authority of the Supervisory Board is regulated in Article 24 Paragraph (3), namely: "giving approval for strategic plans and work plans and annual budgets for the financial management of Hajj; give approval for the placement and/or investment of Financial Hajj; obtain and/or request a report from the Implementing Agency; access data and information regarding the management of Financial Hajj; reviewing data and information regarding the management of Financial Hajj, and provide advice and recommendations to the President through the Minister regarding the performance of the Implementing Agency."

The permissibility of the Wakālah contract in the management of the Hajj funds has been described above, which is based on several verses of the Quran, among others: An-Nisa: 39 and Al-Kahfi: 19. In its implementation, BPIH must also follow some of the rules mentioned above. In addition, it is also based on Article 20 Book II of the Supreme Court Regulation Number 2 of 2018 concerning Compilation of Sharia Economic Law (KHES) (PERMA No. 2, 2008), which states that Contract is an agreement in an agreement between two or more parties to do and or not carry out 
certain legal actions. Furthermore, based on Article 20, Number 19, Book II KHES, Wakālah is giving power to other parties to do something.

Article 21 KHES governs the principles of contract. In the article there are 11 principles of contract, including principles of voluntary/voluntary, trust/keeping promises, ikhțāti/prudence, luzūm/unchanging, mutual benefit, taswiyah/equality, transparency, ability, taisir/ease, good faith and cause the halal. The meaning of the legal cause here is "that the contract made is not contrary to the law, is not prohibited by law and is not illegal."

Pillars and terms of a contract are based on Articles 22 to 25 KHES. The basic principles based on Article 22 KHES include:

1. Conscious parties;

2. Object Covenant;

3. The main purpose of the Covenant;

4. Deal

Contracting parties based on Article 23 KHES are persons, associations or business entities that can carry out legal actions. In this case, the Wakālah contract is between the prospective pilgrims of Hajj and BPIH. Based on Article 24 KHES, the object of the contract is an amwal or service that is permitted by each party. In this study, the object of the contract is the services of BPIH in accepting the Hajj deposit and managing it until the time for the prospective Hajj pilgrims to get a portion to run the Hajj according to the time specified at the time of the contract. The purpose of the contract based on Article 25 KHES is to fulfil the needs of life and business development of each party that holds a contract.

Next will be explained about the categorization of Wakālah contract in the Hajj fund deposit. Based on the description in the literature review above, based on Syamsul Anwar's opinion that the Wakālah Agreement on the Hajj fund deposit is an Unnamed Contract. The definition of unnamed Agreement, according to Syamsul Anwar, is a contract that is not explicitly regulated in the books of fiqh under one particular name (Anwar, 2010). The nameless contract arises because of the interests of the parties and due to the growing needs of the community. The nameless contract, although not specifically regulated, must still fulfil the elements in the contract so that it can become lawful.

Other categorizations can be based on Article 26 KHES by using 'argumentum a contrario'. Article 26 KHES states that the contract is not valid if it conflicts with:

1. Islamic Sharia;

2. Legislation;

3. Public order, and/or;

4. Decency 
Based on the contents of Article 26 KHES with argumentum a contrario then related to a legal contract is a contract that fulfils Islamic law, in accordance with the laws and regulations, public order and morality. Associated with the categorization of contract can be based on Article 27 KHES, which states that the contract law is divided into three categories, namely:

1. Legitimate contract;

2. The contract that is facade/can be cancelled;

3. A contract that is null and void by law

The definition of three contract categorizations explained in Article 28 KHES. "Legitimate contracts are harmonious agreements fulfilled and the conditions. The facade contract is a harmonious agreement fulfilled and the conditions, but there are aspects or other things that damage the contract because of the consideration of the problem. A cancelled contract is a contract that is less harmonious or conditions."

In its implementation, the parties may not conflict with the agreement that has been agreed upon. In the practice of financial management of the Hajj, especially in the initial fund deposits of prospective pilgrims to BPIH, it must be based on the contents of the contract. If BPIH cooperates with BPKH, it will use the funds of pilgrims for the pilgrimage as long as it has not been used, there must be a guarantee for the pilgrims of the Hajj pilgrimage to fulfil their initial purpose in carrying out the Hajj on time.

The Wakālah Contract concerning the initial deposit for prospective pilgrims is regulated according to Article 6 Paragraph (2) of Law Number 34 of 2014 concerning Management of Financial Hajj. This article states that the deposit is paid to the account in the name of BPKH (Hajj Financial Management Agency) as the legal representative of the pilgrims. Based on Article 13 of Government Regulation Number 5 of 2018 concerning the implementation of Law Number 34 of 2018, it stipulates that the initial deposit payment is accompanied by the filling and signing of the Wakālah Agreement form by the pilgrims.

The BPKH Regulation regulates provisions regarding the type, format and requirements of the Wakālah contract. In the Wakālah agreement format, there is a clause stating that the congregation that will pay the initial deposit gives the authority/time to the BPKH to manage all funds paid according to the mandate of the legislation in force from time to time. In its implementation, there was no statement in the format of the Wakālah agreement, which explicitly stated that BPIH's initial deposit funds paid by pilgrims were used for infrastructure financing.

Wakālah agreement is needed to ensure the congregation is willing to fund it managed by BPKH. If there is no Wakālah contract, the funds will become ordinary savings that cannot be managed by BPKH. According to Anggito Abimanyu, as Chairman of the BPKH, said that "the contents of the Wakālah contract or a power of attorney for the initial deposit of the hajj or BPIH fees consist of: 
1. The identity of the prospective pilgrims (name, address and ID number);

2. Statements of authorization from prospective pilgrims in managing funds;

3. Forms of fund management by BPKH, namely placement, investment, the value of benefits, payment of operational costs for hajj, and return;

4. The statement of authorization of prospective pilgrims to BPKH to process receipts, record customer information, cooperate in financial management, and carry out mandates under laws and regulations.

Anggito emphasized that the entire fund management program refers to Law 34 of 2014 and is carried out with the principles of prudence, optimality, benefits, sharia, transparency and professionalism. Anggito further stated that the financial management of the Hajj by the BPKH was carried out to improve the quality of the implementation of the Hajj and the benefit of Muslims. Anggito Abimanyu's opinion is based on Article 3 of Law No. 34 of 2014 which states that the goal of Hajj financial management is to improve the quality of the implementation of Hajj, rationality, efficient use of Hajj costs and benefits for the benefit of Muslims (Primadhany, 2018).

A similar statement was supported by Nazri, who explained that what the community was highlighting was the management of the pilgrimage management. If the pilgrimage fund can be optimized efficiently and productively, it is undoubtedly expected to be very helpful in improving the welfare of the services of Indonesian pilgrims (Nazri, 2013). The substance, format and contents of the Wakālah contract or power of attorney have been discussed and consulted by BPKH to the National Sharia Council (DSN) - Indonesian Ulama Council (MUI).

According to Anggito, the form of a Wakālah contract or power of attorney can be seen and found in all BPS-BPIH counters (banks that receive deposit fees for the administration of the Hajj) throughout Indonesia appointed by BPKH. Regarding applicants for prospective pilgrims, he said the number increased above the target of 550 thousand people through BPS-BPIH. Likewise, all registrants of prospective pilgrims have filled and arrived at the Wakālah agreement sincerely, and understand the meaning of the contract. Anggito hopes that the explanation can answer public unrest regarding the Wakālah contract or the power of attorney registration letter at BPS-BPIH (Abimanyu, 2019).

The legal consequences that can be generated from the misuse of authority and responsibility in managing the pilgrimage fund are losses for prospective pilgrims in the form of postponement of departure or inadequate facilities received by pilgrims. In Article 4 and 5 of Law Number 8 of 1999 concerning Consumer Protection (Law No. 8, 1999), the prospective Hajj pilgrims are entitled to compensation/ replacement, 22 if the goods and services received are not in accordance with the agreement or not while the Muwakkil has fulfilled its obligation to pay the hajj fee to Hajj travel agency. Dispute resolution arising in the management of hajj fund 
deposits can be through the Syariah Arbitration Agency after the agreement was reached without an agreement, this is in accordance with the Fatwa of the National Syariah Council Number 10/ DSN-MUI/IV/2000.

\section{Conclusion}

The legal relationship between the Muwakkil and Wakil (the agent) is based on the Wakālah Contract. The existence of Wakālah Contract in the Hajj fund deposit is a series with the aim of Muwakkil to run the Hajj. Therefore, the management of the hajj deposit funds should be based on applicable laws and regulations, the theory of authority, the theory of dispute resolution and the purpose of the Wakālah Contract. The legal relationship that exists in its implementation is carried out in the first stage between prospective pilgrims and BPIH. In the second stage, there is a legal relationship between BPIH and BPKH that was born from the legislation, as discussed in the previous description.

The categorization of Wakālah contract in the pilgrimage fund deposit is part of the contract intended by the prospective pilgrims to carry out the Hajj. In the series of Hajj implementation during the waiting time, a Wakālah Agreement was issued to optimize the management of Hajj finances. Then the series of contracts that are in the implementation of the Hajj, especially related to legal relationships between prospective pilgrims, the Hajj and BPKH deposit recipient banks can be categorized into Unnamed Contracts and based on their making in accordance with the pillars and Wakālah contract terms and do not conflict with laws and regulations. Valid then the Wakālah Agreement made between pilgrims who are candidates for Hajj and BPIH is a valid contract.

Legal validity and consequences if the use of the Hajj deposit funds contradicts existing laws and agreements and is not in accordance with the intended use, it can have consequences that the Wakālah contract will be null and void and if it contradicts the original agreement between Muwakkil and Wakil then the Muwakkil can submit contract cancellation. In the event of a loss, the BPKH is responsible for compensating the Muwakkil, in this case, the prospective pilgrims.

\section{References}

Abimanyu, A. (2019). Tidak ada klausul infrastruktur dalam akad wakalah haji. Retrieved April 27, 2019, from https://www.indonesiana.id/read/128522/tidak-ada-klausul-infrastrukturdalam-akad-wakalah-haji

Abu Sulaiman, A. W. I. (2006). Banking card syariah, kartu kredit, dan debit dalam perspektif fikih. Jakarta: Raja Grafindo Persada.

Ali, H. (2019). Disharmonization of wakalah agreement in Law Number 34 of 2014 and The DSN-MUI Fatwa Number 122/DSN-MUI/II/2018. Al-Iqtishad: Jurnal Ilmu Ekonomi Syariah, 11(1). https://doi.org/10.15408/aiq.v11i1.11144

Anwar, S. (2010). Hukum perjanjian syariah. Jakarta: Raja Grafindo Persada. 
Azhara, A. (2015). Manajemen dana tabungan haji ditinjau dari perspektif ekonomi Islam pada PT. Bank BNI Syariah dan PT. Bank Syariah Mandiri Palangkaraya (IAIN Palangkaraya). Retrieved from http://digilib.iainpalangkaraya.ac.id/73/

Aziz, R. M. (2018). Hahsim Theory as guidance of straight path in management of Hajj and finance. KnE Social Sciences, 3(8), 105. https://doi.org/10.18502/kss.v3i8.2503

Garner, B. A. (2009). Black's law dictionary (9th Editio). West Publishing Co. Thomson Reuters.

Hadjon, P. M. (1997). Tentang wewenang. Yuridika1, 7(5). Retrieved from https://ejournal.unair.ac.id/YDK/article/view/5769/3691

Jayaprawira, A. R., \& Abdussalam. (2019). Analysis of the implementation of the Islamic contract principle on Hajj Fund Management by Hajj Fund Management Agency (BPKH). KnE Social Sciences, 3(26). https://doi.org/10.18502/kss.v3i26.5405

Jumali, E. (2018). Management of Hajj funds in Indonesia. Journal of Legal, Ethical and Regulatory Issues, 21(3), 1-9.

Jumena, J., Bustomi, I., \& Fatimah, S. (2018). Hak jamaah haji atas hasil pengelolaan setoran awal biaya penyelenggaraan ibadah haji. Al-Mustashfa: Jurnal Penelitian Hukum Ekonomi Syariah, 3(2), 237. https://doi.org/10.24235/jm.v3i2.3728

Mubarak, M. A., \& Fuhaidah, U. (2018). Manajemen pengelolaan dana haji Republik Indonesia (Studi kolaborasi antar lembaga BPKH, KEMENAG dan mitra keuangan dalam pengelolaan dana haji). ILTIZAM Journal of Sharia Economic Research, 2(2), 67. https://doi.org/10.30631/iltizam.v2i2.165

Muheramtohadi, S. (2019). The use of Hajj fund for investment purpose: A maqashid sharia approach. Journal of Islamic Economics, Management, and Business, 1(1), 119-136. https://doi.org/10.21580/jiemb.2019.1.1.3740

Muneeza, A., Sudeen, A. S. T., Nasution, A., \& Nurmalasari, R. (2018). A comparative study of Hajj fund management institutions in Malaysia, Indonesia and Maldives. International Journal of Management and Applied Research, 5(3). Retrieved from https://www.ceeol.com/search/article-detail?id=706980

Nazri, R. (2013). Bank Haji Indonesia: Optimalisasi pengelolaan dana haji untuk kesejahteraan jama'ah haji Indonesia (Sebuah Gagasan). Khazanah, 6(1), 1326. https://doi.org/10.20885/khazanah.vol6.iss1.art2

Nurmayani. (2009). Hukum administrasi daerah. Bandar Lampung: Universitas Lampung.

Primadhany, E. F. (2018). Tinjauan terhadap tanggung jawab Badan Pengelola Keuangan Haji (BPKH) dalam melakukan penempatan dan/atau investasi keuangan haji. JURISDICTIE, 8(2), 125. https://doi.org/10.18860/j.v8i2.4447

Purnamasari, I. D., \& Suswinarno. (2011). Akad syariah. Bandung: Mizan Pustaka.

Rasyid, S. (1991). Fiqh Islam. Bandung: Sinar Baru Algesindo.

Ridwan H.R. (2013). Hukum administrasi negara. Jakarta: Raja Grafindo Persada. 
Septiana, N. I. (2015). Konstruksi model pengelolaan keuangan haji pada Bank Syariah di Indonesia (UIN Sunan Kalijaga). Retrieved from http://digilib.uinsuka.ac.id/17420/1/BAB I\%2C V\%2C DAFTAR PUSTAKA.pdf

Stroink, F. A. M., \& Steenbeek, J. G. (1989). Inleiding in het staats-en administratief recht. Holland: Samsom H.D. Tjeenk Willink.

Suhendi, H. (2014). Fiqh Muamalah. Jakarta: Rajawali Press.

Usman, R. (2003). Pilihan penyelesaian sengketa di luar pengadilan. Bandung: Citra Aditya Bakti.

Zubaedi. (2016). Analisis problematika manajemen pelaksanaan haji Indonesia (Restruturisasi model pengelolaan haji menuju manajemen haji yang modern). Manhaj Jurnal Penelitian Dan Pengabdian Masyarakat, 5(3). https://doi.org/http://dx.doi.org/10.1161/mhj.v4i3.182 